\title{
Reasonable Grounds? The Delayed Introduction of MMR Vaccine in Denmark and the Netherlands, 1977-87
}

\author{
ANNE HAGEN BERG ${ }^{1 *}$ and STUART S. BLUME ${ }^{2}$ \\ ${ }^{1}$ Department of History, University of Southern Denmark, Campusvej 55, \\ 5230 Odense M, Denmark \\ ${ }^{2}$ Faculty of Social and Behavioural Sciences, University of Amsterdam, \\ Netherlands
}

\begin{abstract}
It is commonly argued that the decision to introduce a new vaccine is properly based on objective and measurable criteria, including disease burden and efficacy of the vaccine. Moreover, new vaccines are to be introduced rapidly and globally: delay is difficult to justify. Historical studies of new vaccine introductions paint a rather different and more complex picture. The few studies comparing new vaccine introduction in different countries suggest that 'evidence' for the efficacy of a vaccine was commonly subjected to varying interpretations. This paper, based on analysis of the introduction of the measles-mumps-rubella (MMR) vaccine in Denmark and the Netherlands, takes this argument further. Though both countries are - and were - small welfare states with well-organised national immunisation programmes, both adopted MMR a full decade after its introduction in the USA. The paper suggests that the reasons for delaying, in each case, are a reasonable reflection of each country's concerns, perceptions of the three diseases, and technological approaches already adopted. There were differences in each of these respects. The decision to adopt MMR, which each country eventually took, was significantly influenced by the political and ideological changes taking place in the 1980s, including a growing emphasis on costs and benefits, as well as the growing influence of the international context.
\end{abstract}

Keywords: Combination vaccines, New vaccine introduction, Cost benefit analysis, Path dependency, Public sector vaccine institute

\section{The Politics of New Vaccine Introduction}

Among the themes which dominate current discussions of vaccine policy are the importance of innovating rapidly on the one hand, and the articulation of a rational basis

* Email address for correspondence: anneberg@sdu.dk

We would like to thank the Medical History referees for insightful and helpful comments on an earlier draft of this paper. 
for decision-making on the other. ${ }^{1}$ Accelerating the development and introduction of new vaccines has become a cornerstone of global public health, in which the Global Alliance for Vaccines and Immunisation (GAVI) has been the key actor since its establishment in $2000 .^{2}$ Since the importance of rapidly introducing a new vaccine is now taken for granted in much current policy, delay then becomes a deviation in need of analysis and correction.

The idea that decisions regarding new vaccine introduction are, properly, based on objective criteria, notably disease burden and on the cost-effectiveness of an available vaccine, is widespread in policymaking. For example, a decade ago, considering the future of the Dutch national immunisation programme (NIP), a committee of the Health Council (Gezondheidsraad) defined seven criteria for the basis on which introduction of a new vaccine should be based, among which disease burden and cost-effectiveness were most prominent. ${ }^{3}$ Most decision-making frameworks to be found in the public health literature are similar. ${ }^{4}$ It is made to appear totally rational. Decisions regarding a change to the NIP appear to follow simply and rationally from the objective application of clear criteria, free of bias, lobbying or ideology. ${ }^{5}$ With more and more vaccines becoming available, the need not only to choose, but also to justify choices politically is becoming all the greater.

By contrast with the above, Baker has suggested that distinctive national styles of vaccine innovation could be identified, at least for the middle years of the twentieth century. Considering the introduction of four paediatric vaccines (diphtheria antitoxin and the pertussis, polio and measles vaccines), he argues that whereas in the US vaccine development and implementation were marked by a 'current of urgency', the more cautious British set much higher standards for the evidence required to prove the safety and effectiveness of a new vaccine before deciding on its introduction. ${ }^{6}$

The idea that scientific and epidemiological data do not in themselves determine vaccine policy is borne out by analyses of current decision-making processes. ${ }^{7}$ It is also supported by historical research. In her analysis of the introduction of hepatitis B vaccine in the UK, Stanton emphasises the importance of structures of decision-making. "Although vaccine policy was set by the Department of Health,' she concludes, '... it was implemented by regional health authorities. As with other historical examples, the delegation of final

\footnotetext{
${ }^{1}$ Sidsel Roalkvam, Desmond McNeill and Stuart S. Blume (eds), Protecting the World's Children: Immunisation Policies and Practices (Oxford: Oxford University Press, 2013).

${ }^{2}$ William Muraskin, 'The Last Years of the CVI and the Birth of GAVI', in M. Reich (ed.), Public-Private Partnerships for Public Health (Cambridge: Harvard Centre for Population and Development Studies, 2002), 115-68.

${ }^{3}$ De toekomst van het Rijksvaccinatieprogramma: naar een programma voor alle leeftijden (2007/02). In the annual reports on the Danish childhood immunisation programme, six similar criteria are defined. See Børnevaccinationsprogrammet. Årsrapport 2017 (2018).

${ }^{4}$ Example A.J. Vyse, N.J. Gay, J.M. White, M.E. Ramsay, D.W.G. Brown, B.J. Cohen, L.M. Hesketh, P. MorganCapner and E. Miller, 'Evolution of Surveillance of Measles, Mumps, and Rubella in England and Wales: Providing the Platform for Evidence-Based Vaccination Policy', Epidemiologic Reviews, 24,2 (2002), 12536; Barbara Jauregui, A.G.F. Garcia, C.B. Janusz, J. Blau, A. Munier, D. Atherly, M. Mvundura, R. Hajjeh, B. Lopman, A.D. Clark, L. Baxter, R. Hutubessy, C. de Quadros and J.K. Andrus, 'Evidence-Based DecisionMaking for Vaccine Introductions: Overview of the ProVac International Working Group's experience', Vaccine, 33S, 1 (2015), A28-33.

${ }^{5}$ For an approach to policymaking more generally, see John Kingdon, Agendas, Alternatives, and Public Policies (New York: Longman, 1995).

6 J.P. Baker, 'Immunization and the American Way: 4 Childhood Vaccines', American Journal of Public Health, 90, 2 (2000), 199-207.

${ }^{7}$ Lauren Wallace and Lydia Kapirir, 'How are New Vaccines Prioritized in Low-Income Countries? A Case Study of Human Papilloma Virus Vaccine and Pneumococcal Conjugate Vaccine in Uganda', International Journal of Health Policy and Management, 6, 12 (2017), 707-20.
} 
responsibility for decisions about who should receive the vaccine, from the centre to the peripheries, acted as a very effective brake on the wider uptake of the vaccine. ${ }^{8}$ Delegation allows not only for differences in priorities to come into play, but also for differing interpretations of available evidence.

Comparative historical analysis of national responses to the development of a new vaccine can further highlight influences or assumptions that might otherwise be invisible, because unarticulated. It can also help us understand better how scientific and epidemiological data can be differently construed, depending on the context. Bryder's analysis of responses to the development of BCG (Bacillus Calmette-Guérin) vaccine, in the early 1920 s, is exemplary in this respect. ${ }^{9}$ Her analysis stresses the importance of distinctive national traditions and professional commitments in shaping responses to the emergence of BCG.

Both Stanton and Bryder emphasise the non-determinant character of scientific and medical data. Similarly, in their analysis of the introduction of the polio vaccines in Britain, Germany and the Netherlands, Lindner and Blume argue that epidemiological data, and studies of the (relative) merits of the two polio vaccines, were subjected to interpretations that differed from country to country. ${ }^{10}$ Studies could be, and were, differently constructed and reconstructed by political actors. Structural features of health systems also played an important, though not determining, role in explaining these national differences. Moreover, and in line with much current innovation theory, Lindner and Blume suggest that different responses to the emergence of the polio vaccines also reflected differences in linkage between national systems of vaccine production and of public health. In the Netherlands, though not in Britain or Germany, there existed a state vaccine producer with the specific responsibility of responding to the needs of the NIP.

Denmark and the Netherlands offer a particularly appropriate basis for comparison. Both are small West European countries with highly developed welfare states. Both have well-established NIPs, centrally planned and financed but locally administered. That of the Netherlands (the Rijksvaccinatieprogramma) was established in 1957, with administration delegated to provincial entities known as Provinciale Entadministraties (PEAs). In Denmark a framework law, the so-called 'vaccination law', came into force in spring $1977 .{ }^{11}$ Whereas previously vaccines had been introduced on the basis on a vote in parliament, the new law authorised the Minster for the Interior to make changes in the NIP on the basis of recommendations from the National Board of Health (Sundhedsstyrelsen). Most health care ${ }^{12}$ was funded from taxes and administered de-centrally. ${ }^{13}$ The costs of vaccinations were divided between central and local level: the state financed the production/import and distribution of vaccine and the counties paid the GP's fee for administering the vaccinations. In both Denmark and the Netherlands free vaccinations against a limited number of diseases have been offered for many years.

\footnotetext{
8 Jennifer Stanton, 'What Shapes Vaccine Policy? The Case of Hepatitis B in the UK', Social History of Medicine, 7 (1994), 427-46.

9 Linda Bryder, "'We Shall Not Find Salvation in Inoculation”: BCG Vaccination in Scandinavia, Britain and the USA, 1921-1960', Social Science \& Medicine, 49 (1999), 1157-67.

${ }^{10}$ Ulrike Lindner and Stuart S. Blume, 'Vaccine Innovation and Adoption: Polio Vaccines in the UK, the Netherlands and West Germany, 1955-1965', Medical History, 50 (2006), 425-46.

11 Act no. 634 of 17 December 1976.

12 Some types of health care, such as adult dentistry and physiotherapy, requires co-payment by the patients.

${ }^{13}$ For a fuller discussion on the Danish health care system, see Kjeld Møller Pedersen, Terkel Christiansen and Mickael Bech, 'The Danish Health Care System: Evolution - Not Revolution - in a Decentralized System', Health Economics, 14 (2005), S41-51.
} 
Moreover Denmark, like the Netherlands, had until recently a long-established and highly regarded public sector vaccine producer. In both countries these institutes had the responsibility for supplying vaccines required by the NIP, whether by in-house production or purchase.

In this paper we focus on the introduction of the combination measles-mumps-rubella (MMR) vaccine in each of the two countries. When, how and on the basis of what considerations was the vaccine introduced? We will suggest that, in addition to a changing ideological climate and growing emphasis on costs and benefits, specific national issues also played a role. These include the significance attached to each of the diseases, as well as the commitments made and arrangements already in place when the MMR vaccine became available. This 'path dependency', which is a more general phenomenon, reflects a tendency for solutions and institutions to be 'locked in' to certain paths, due to economic interests and accumulating institutional commitments. ${ }^{14}$ We argue further that the introduction of combination vaccines poses different challenges to policymakers than monovalent vaccines, a theme that has largely been overlooked in historical scholarship.

\section{The Origins of the Measles-Mumps-Rubella (MMR) Vaccine}

Building on John Enders' successful cultivation of the polio virus and the subsequent development of inactivated (Salk) and live (Sabin) polio vaccines, in the 1960s numerous institutions were trying to develop vaccines against other viral diseases. These diseases included measles, rubella and mumps. In each case, because different (local) strains were taken and processed in different ways, various alternative vaccines emerged. Discussion of the relative merits of the different measles, mumps and rubella vaccines was gradually transformed by the emergence of combined vaccines. The major argument for combining different vaccines was, and is, that schedules can be simplified, and so uptake increased. At Merck, Maurice Hilleman had begun studying antibody responses to various vaccine combinations, including the three-component measles-mumps-rubella, in $1969 .{ }^{15}$ In his history of Merck's vaccine work, Louis Galambos discusses the technical challenges that development of a combination vaccine presented. It was necessary to ensure that the three vaccines did not interfere with each other, and that reactogenicity (any excessive responses and minor adverse effects) was no greater than when the vaccines were given individually. ${ }^{16}$ Commercial considerations also played a role; as Galambos explains: '[I]t was also possible that a Merck product would be squeezed out of the market by the widespread use of another firm's combination vaccine.' The diphtheria pertussis tetanus (DPT) vaccine was in widespread use and attempts to combine it with measles vaccine were known to be underway. Since Merck did not produce a DPT vaccine, commercial considerations dictated development of an alternative combination. ${ }^{17}$ On the basis of clinical tests carried out by the University of Pennsylvania Medical School, Hilleman's

\footnotetext{
14 See David Wilsford, 'Path Dependency, or Why History Makes It Difficult but Not Impossible to Reform Health Care Systems in a Big Way', Journal of Public Policy, 14, 3 (1994), 251-83; Stuart S. Blume, 'Lock in, the State and Vaccine Development: Lessons from the History of Polio Vaccines', Research Policy, 34 (2005), 159-73. On path dependency, see Paul Pierson, 'Increasing Returns, Path Dependence, and the Study of Politics', American Political Science Review, 94, 2 (2000), 251-67; James Mahoney, 'Path Dependence in Historical Sociology', Theory and Society, 29 (2000), 507-47.

15 Maurice R. Hilleman, 'Toward Control of Viral Infections in Man', Science, 164 (1969), 506-33.

${ }^{16}$ Louis Galambos with Jane E. Sewell, Networks of Innovation: Vaccine Development at Merck, Sharp \& Dohme, and Mulford, 1895-1995 (Cambridge: Cambridge University Press, 1995).

${ }^{17}$ Ibid., footnote 113 .
} 
combination MMR vaccine was deemed safe and effective. The new combination vaccine was licensed in 1971, alongside the individual antigens. Merck soon became the only domestic supplier of MMR vaccine in the USA.

By the mid-1970s MMR was being used routinely in the USA, in place of the individual vaccines. The situation in Western Europe was different. Since coverage was generally much higher than in the United States, the need to simplify schedules and increase uptake was less acute. Public health authorities hesitated, and most European countries continued using the individual vaccines against measles and/or rubella. It was only in the course of the 1980s - a decade after the USA - that Western European countries began to use MMR. For instance, in Sweden, Finland and Italy it was introduced in 1982, in Norway in 1983, in France and Luxembourg in 1986, and in the UK in $1988 .{ }^{18}$ Both Denmark and the Netherlands introduced MMR to their national immunisation programmes in 1987. How this came about, the routes and the arguments, were however quite different. In the following sections of the paper we examine what was involved in each of the two countries.

\section{MMR Introduction in Denmark}

When Denmark began universal MMR childhood vaccination in 1987 , it did so against a distinctive background. In contrast to most industrialised countries, Denmark had not previously vaccinated against either measles or rubella. The decision-making process that eventually led to MMR introduction entailed several distinct elements: (a) the construction of measles, mumps and rubella as health threats and of universal vaccination as the preferred response to them; (b) harmonisation of the problems so that a combination vaccine could be administered instead of three different vaccines; and (c) establishment of political consensus. The Danish case exemplifies structures and hierarchies of power, but also how local authorities could challenge and ultimately overrule the central authorities.

Since the 1940s, rubella had been considered a serious threat to public health because of the risk of congenital rubella syndrome (CRS). It was, however, handled as a health threat to individual women. In 1969, as the first rubella vaccines were licensed, the State Serum Institute (SSI) presented what would become the standard Danish strategy against CRS over the following two decades. SSI had contributed to the international field of vaccination development throughout the twentieth century, ${ }^{19}$ but it did not set about developing a rubella vaccine, and nor, initially, did it import the vaccine from abroad. Instead, in 1969 its new 'rubella laboratory' developed a method for serologic screening of blood samples for rubella antibodies. While rubella had been designated as providing legitimate grounds for legal abortion since 1954, it was often difficult to diagnose. The screenings had the potential to provide many pregnant women with the certainty that allowed them to have an abortion, and the screenings were used by increasing numbers of women. Not only did vaccination therefore appear superfluous, but SSI questioned both the safety of the vaccine and the duration of vaccine-induced immunity. ${ }^{20}$ If the duration of immunity was short, many young women would later be susceptible to infection. They had

\footnotetext{
18 See chart in Stanley Plotkin, Walter Orenstein and Paul Offit (eds), Vaccines (Philadelphia: Saunders, 2008), 5th edition, 431. Regarding Norway, see Maria Hagerup-Jenssen, 'Suboptimal MMR2 Vaccine Coverage in Six Counties in Norway Detected Through the National Immunisation Registry, April 2014 to April 2017', Eurosurveillance, 22, 17 (2017), 305-18.

${ }^{19}$ Klaus Jensen, Bekcempelse af infektionssygdomme. Statens Serum Institut 1902-2002 (Copenhagen: Statens Serum Institut, 2003).

${ }^{20}$ Jørgen Leerhøy and Herdis von Magnus, 'Rubellavacciner', Ugeskrift for Lager, 135, 12 (1973), 637-40.
} 
not been naturally (and permanently) immunised by infection during childhood, and were potentially no longer protected by the vaccination they had received in childhood. The health authorities believed that vaccinating children could potentially lead to increasing numbers of CRS cases and that screening was therefore the safest and best solution.

The preference for limiting CRS through screening and (where indicated) abortions instead of through prevention seems curious. This preference can however be understood in terms of technological path dependency. The screening technology had been developed in SSI itself and introduced simultaneously with the US licensing of the rubella vaccine. The subsequent reluctance to change can be seen as reflecting not only a preference for the 'home grown' technology, but also institutional constraints and potential costs. Switching to vaccinations would entail significant changes in the SSI; for instance, it would be hard to justify the existence of the rubella laboratory if rubella serology were no longer performed.

However, the screening programme had two shortcomings. First, it relied on a woman herself, or the family doctor, enrolling in the programme. This meant that unknown numbers of pregnant women might not be aware of the rubella associated risk or of the possibility of being screened. Second, the system was vulnerable to fluctuating demand because of the laboratory's limited capacity. Due to these uncertainties, CRS would continue to be a problem. To establish better prevention, the programme was later expanded to women who were planning to become pregnant. ${ }^{21}$ Despite their reluctance, in 1975 the SSI nevertheless started to import vaccine due to public demand, especially from young women. ${ }^{22}$ This demand was initially vocalised by heads of paediatric hospital wards where young nurses were concerned. Once import had started, GPs could order rubella vaccine when patients asked for it. In contrast to NIP vaccines, these required payment.

SSI considered whether to develop a measles vaccine in the 1940s but chose not to. Based on a 1973 report on the epidemiology of measles in Denmark, the National Board of Health concluded that there was no need for general measles vaccination since measles did not pose a threat to otherwise healthy children under Danish conditions. ${ }^{23}$ Moreover - as in the case of rubella vaccinations - the likely effects of a vaccination programme could not as yet be known. However, they did recommend vaccination for chronically ill children, and the SSI began a small import of vaccine. Furthermore, measles vaccine was introduced in the Greenlandic childhood vaccination programme in 1976. Greenland was, and is, part of Denmark and the Ministry for the Interior was responsible for public health in both places (in Greenland in collaboration with the Ministry for Greenland). The different strategies in Denmark and Greenland reflect how the authorities assessed the need for new vaccines in each of the two regions. Besides the fact that Greenlandic people were very susceptible to infection because measles had been virtually unknown there, the infrastructure on the island made the risk higher. Most people lived in small rural settlements, scattered along the coastline, which could only be accessed by ship, helicopter or dog sleigh, and many of these settlements had no health personnel to care for the sick and provide medication to treat complications. By contrast, Denmark had a modern and readily accessible health care system.

${ }^{21}$ Ibid., 639 .

22 'Meddelelse af 12.XII.1974', Ugeskrift for Lager, 137, 2 (1975), 110.

${ }^{23}$ O. Horwitz, K. Grünfeld, B.L. Hansen and K. Kjeldsen, 'Mæslinger i Danmark. Epidemiologi og klinisk forløb vurderet ud fra en landsomfattende stikprøve', Fra Sundhedsstyrelsen, VI, 13 (1973), 145-53; 'Mæslinger og mæslingevaccination. Kommentar fra Sundhedsstyrelsens arbejdsgruppe vedrørende vaccinationsproblemer', Fra Sundhedsstyrelsen, VI, 13 (1973), 154-6. 
In the 1970s, the NIP included only vaccines against fatal and crippling diseases: measles, mumps and rubella were neither. The question of vaccine-related risks thus played a more significant role. For example, in a 1972 discussion about measles vaccine, SSI pointed out that

the [vaccination related] complications of course increase in importance, the more we move from vaccines against serious diseases (tetanus, polio, diphtheria, pertussis) to vaccines against infections that usually proceed fairly mildly, and where vaccination of the children may to some extent take place on socio-economic indication. ${ }^{24}$

However, over the following few years, the public demand for measles vaccine rose. ${ }^{25}$ In 1978, also due to public demand, SSI started to import mumps vaccine. Orchitis was a known complication of mumps and - at least theoretically - it could lead to sterility. Previously mumps had been of no interest to health authorities and professionals, which is reflected in its absence from archives and medical journals before 1978. But the risk of sterility became a recurring theme in the newspapers through the 1970s and 1980s, ${ }^{26}$ and in 1982 SSI reported on 'numerous enquiries' about mumps, sterility and prophylaxis. ${ }^{27}$

The fact that MMR vaccine was not introduced in the late 1970s derived from careful consideration of Denmark's needs, and of existing practices. But from the late 1970s, a series of events led to rethinking and new recommendations. In 1977 a rubella epidemic exposed the weakness of the screening system, as SSI was unable to meet the resulting surge in demand. This led to the reframing of rubella as a public health problem rather than a problem for individual women, and this reframing made it possible to switch to vaccinations. Lacking the capacity to screen large numbers of blood samples simultaneously, as was needed during the epidemic, it became necessary to prioritise samples from women who showed rubella symptoms. Instead of the usual one or two days, women who had been exposed to rubella but did not have any symptoms had to wait several weeks for their test results. This was highly problematic, as rubella was often symptom-free, and the long wait meant that women could cross the abortion limit of twelve weeks.

In the wake of the epidemic, the National Board of Health issued a recommendation for a rubella vaccination programme aimed at 18 -year-old women and women planning for pregnancy. ${ }^{28}$ The purpose was to immunise the individual woman to prevent CRS. Duration of protection offered by the vaccine was still considered uncertain, and this schedule was chosen to vaccinate women as close to a possible pregnancy as possible, ${ }^{29}$ without the risk of accidentally vaccinating pregnant women. The vaccinations were intended only for non-immune women, because it was considered problematic to vaccinate already immune people. This further established the superiority of and need for screenings, and these became a cornerstone in the suggested programme. The health authorities estimated that by eighteen years of age, eighty-five per cent of people had already had

\footnotetext{
${ }^{24}$ Herdis von Magnus, 'Spørgsmål og svar: mæslingevaccination’, Ugeskrift for Lager, 134, 8 (1972), 395. Our translation.

25 'Mæslingevaccine', EPI-NYT, week 501982.

${ }^{26}$ Example 'Han er blevet steril', Skive Folkeblad, 22.09.1972, 14; 'Ny behandling mod frygtet sygdom', Aarhuus Stiftstidende, 08.02.1975, 3; 'Fåresyge kan medføre sterilitet hos mænd', Holstebro Dagblad, 22.02.1977, 7; 'Fåresygen kan give sterilitet hos mænd, men det er sjældent', B.T., 03.07.1979, 17; 'Du kan blive steril af fåresyge', B.T., 12.02.1982, 21.

27 'Parotitis epidemica', EPI-NYT week 71982.

${ }^{28}$ National Archives, Ministry for the Interior 3rd Health Office, 1973-1977, box 117, file 5312-9, letter dated 16 August 1977, memos dated 18 August, 24 August and 29 August 1977.

${ }^{29}$ Most Danish children were born to mothers ages between 20-30, so 18 years was appropriate.
} 
rubella and were thus naturally immune. All 18-year-old females should be tested and only the estimated fifteen per cent who were still susceptible to rubella would be offered the vaccine. The change from a well-established screening programme to a vaccination programme was substantiated by the fact that screening alone did not fully solve the problem. CRS-affected babies were still being born, and an unknown number of abortions were being performed annually due to rubella. Vaccination could solve both problems.

The recommended programme required various forms of investment. The National Board of Health estimated that 35000 blood samples would have to be analysed annually, though they expected 100000 annual tests in the first few years. These numbers far exceeded what the laboratory had handled thus far. Furthermore, larger quantities of vaccine had to be imported and distributed, and the doctors would have to be paid for both handling the blood samples and administering the vaccine. Finally, 18-year-old women should receive an invitation to the programme, which demanded continuous extraction of data from the Civil Registration System. ${ }^{30}$ Still, the authorities concluded that it would be cheaper than vaccinating all young women, since on a per case basis screening was considerably cheaper than vaccination. This argument was reiterated in later discussions of MMR. ${ }^{31}$

Tight fiscal politics made general rubella vaccinations hard to justify politically. In the 1970s and the 1980s successive Danish governments tried to reduce public sector spending, not least on tax-funded health care. ${ }^{32}$ A few months before the epidemic, in early 1977 , budget cuts had caused SSI to lay off several laboratory technicians. Having already struggled to meet demand during the epidemic, SSI stated that it would not be able to handle extra blood samples in the future without extra staff. The government refused to provide additional funds. What made the introduction of rubella vaccine difficult was the reluctance to abandon the technology that had been developed and established at SSI itself. This would have to change if the vaccine were to be introduced.

After an initial discussion in 1981 the health authorities changed their focus to MMR, ${ }^{33}$ and in March 1983 the National Board of Health recommended an extension of the NIP with the MMR vaccine. ${ }^{34}$ For six years there should also be a catch-up programme aimed at 18-year-old women until the first cohort of 12-year-old vaccinees turned eighteen. The recommendation reflects how the diseases were reconstructed to justify the introduction of MMR.

Cases of CRS were a well-established input to discussion, but these were now supplemented by consideration of prevention strategies in other countries. Most European countries vaccinated schoolgirls to establish individual protection, but the USA vaccinated young children of both sexes in order to stop the circulation of the virus. The National Board of Health recommended a 'combination strategy' involving vaccinating young children (age fifteen months) and school children (age twelve years). They argued that to protect the women best, virus circulation should be prevented. As one official stated, if the children could infect each other in day care centres and schools, they could still bring

\footnotetext{
30 The national register containing basic information on all residents.

${ }^{31}$ National Archives, Ministry of Health, 4th Office, 1983-1987, box 137, file 5320-24, letter from National Board of Health dated 30 January 1986.

32 According to note from the Ministry of Finance, March 1984.

${ }^{33}$ National Archives, Ministry for the Interior, 3rd Health Office, box 177, folder 5312-9, minutes from meeting dated 12 August 1981.

${ }^{34}$ National Archives, Ministry of Health, 4th Office, 1983-1987, box 131, folder 5312-1, letter dated 29 March 1983.
} 
rubella home to their pregnant mothers. They estimated that ninety-five per cent of those vaccinated would form antibodies. It followed that even if all women were vaccinated, a few would still be susceptible. These would now be protected by the immunisation of the children.

The twofold strategy also fitted perfectly with a combination vaccine programme aimed at children, i.e. one that also included measles vaccine. Measles, which had previously been viewed as innocuous, had now become a 'potentially serious disease', as the earlier differentiation between chronically ill children and otherwise healthy children was removed.

This is a significant change; now all children were seemingly equally at risk of serious complications, possibly death, which legitimised general vaccination. According to the recommendation, five to six Danish children died from measles annually. Furthermore, it caused at least three cases of brain damage each year, and 4500 children had bacterial complications that called for medication and in some cases resulted in hospitalisations. International obligations also played a role. In the late 1970s the global control of measles was on the agenda of the World Health Organization (WHO). In 1977, the Expanded Programme on Immunization (EPI) designated six diseases against which all the world's children should be offered vaccination, among them measles. ${ }^{35}$ Also in 1977, World Health Assembly adopted the WHO resolution 'Health for All by the Year 2000', and in 1979 the 'Global Strategy for health for all' was launched. In it the need to tackle measles globally was reiterated. ${ }^{36}$ Denmark, as part of the WHO European Region, committed itself to the HFA2000, and in 1983 the WHO criticised Denmark for being a 'net exporter' of measles. ${ }^{37}$ This was beginning to be considered problematic by the Danish authorities, and in 1985 the National Board of Health and members of the Parliament pointed out that all countries 'except Denmark and India' vaccinated routinely against measles. ${ }^{38}$

The primary argument for vaccination against mumps was financial. While mumps was not considered serious, it did lead to some 3000 hospitalisations annually. The introduction of the combination MMR vaccine would prevent these without extra costs or efforts.

MMR became an object of political discussions in the years following the 1983 recommendation. The consideration that came to dominate was costs and savings rather than health benefits. Initiated by the Minister for the Interior, in October 1983 the National Board of Health established a working group to conduct a cost-benefit analysis of MMR. Michael von Magnus, the chief physician on the Board, questioned the need for this. He pointed out that 'no other countries had found it necessary to do so thorough costbenefit analyses before adopting MMR' ${ }^{39}$ In February 1984 the cost-benefit working group submitted its report, documenting that while the programme would cost sixty-eight million kroner over twenty years, the savings in the same time period would be 201 million kroner. $^{40}$ The net savings would be 133 million kroner over twenty years. However, the

${ }^{35}$ K. Keja, C. Chan, G. Hayden and R.H. Henderson, 'Expanded Programme on Immunization', World Health Statistics Quarterly, 41, 2 (1988), 59-63.

${ }^{36}$ Global Strategy for Health for All by the Year 2000 (Geneva: World Health Organization, 1981), 76.

${ }^{37}$ National Archives, National Board of Health, 1982-1992, box 258, folder 4120-1-1983, letter dated 15 March 1983.

38 'Forslag til folketingsbeslutning om indførelse af MFR-vaccination', Tillaeg A til Folketingstidende, Folketingsåret 1985-86, (Copenhagen: J. H. Schultz, 1987), 4290.

${ }^{39}$ National Archives, Ministry of Health, 4th Office, 1983-1987, box 131, folder 5312-1.

40 The report was published the following year as Vaccinationsudvalget, Økonomisk vurdering af vaccination mod maeslinger, fåresyge og røde hunde i Danmark: Redegфrelse (Copenhagen: Sundhedsstyrelsen, 1985) and in 
programme would require continuous investments by the central government, while the savings would go to the counties that financed and administered the health care sector. Because of this, the Ministry was unable to introduce MMR. This may seem odd but reflects how public sector economics were understood as separate columns in the 1980s, even if the funding came from the same state budget. The MMR analysis was the first cost-benefit analysis used in Danish health care politics, and politicians were unable or unwilling to see how the costs and benefits in different sectors could balance each other out. $^{41}$

The lack of an MMR vaccination programme was increasingly a matter of debate and criticism. In the Parliament (Folketinget), the Social Liberal Party (Radikale Venstre) raised the question of the vaccine in early 1985 and early 1986 to put pressure on the Minister for the Interior. Furthermore, SSI experienced continuous interest in and demand for MMR, ${ }^{42}$ so in the spring of 1985 they started to import the trivalent vaccine, Virivac, purchased from the Swedish SBL. ${ }^{43}$ A rapidly growing number of parents were having their children vaccinated against measles, ${ }^{44}$ and SSI argued that these children could benefit from immunisation against mumps and rubella without extra effort or side effects. Furthermore, SSI wanted to develop knowledge of the effects and possible side effects while waiting for a national MMR programme.

In the event, however, the final stimulus to universal vaccination with MMR did not come from the central health authorities, but from a challenge originating in a lower level of government administration. The Association of County Councils in Denmark (Amtsrådsforeningen) started taking matters into its own hands. Aware of the outcome of the cost-benefit analysis, they began planning a locally based MMR programme in spring 1985. This was a deviation from the regular policymaking process, as changes in the health care sector were typically initiated and organised by the central authorities. Over the following months, most Danish counties declared that they would introduce MMR, and by December 1985 the Association had developed a comprehensive plan that included financing. ${ }^{45}$

The counties' plan seems to have been the determining factor. A locally administered vaccination programme was too vulnerable, as uneven coverage could lead to an epidemiological shift towards older age groups. If less than ninety-five per cent of children were vaccinated, it would slow down the circulation of virus, but not eliminate it, leaving non-immune adults more at risk. This possibility concerned the central health authorities,

the following journal articles: P. Bjerregaard, K.M. Pedersen, F. Kamper-Jørgensen, C. Koch, F.K. Pedersen, A.L. Wagner and H. Zoffmann, 'Vaccination mod mæslinger, fåresyge og røde hunde I: lægelige og epidemiologiske aspekter', Ugeskrift for Lager, 147, 38 (1985), 3013-17; P. Bjerregaard, K.M. Pedersen, F. Kamper-Jørgensen, C. Koch, F.K. Pedersen, A.L. Wagner and H. Zoffmann, 'Vaccination mod mæslinger, fåresyge og røde hunde II: samfundsøkonomisk analyse', Ugeskrift for Lager 147, 38 (1985), 3017-22.

${ }^{41}$ Kjeld Møller Pedersen, Sundhedspolitik. Beslutningsgrundlag, beslutningstagen og beslutninger $i$ sundhedsvaesenet (Odense: Syddansk Universitetsforlag, 2005), 76-81.

42 'Mæslingevaccination', EPI-NYT week 47 1982; 'Børnevaccinationer', EPI-NYT week 47 1983; 'MFRvaccination', EPI-NYT week 10 1984; 'MFR-vaccination', EPI-NYT week 35 1984; 'Mæslinge-parotitisrubellavaccine (MFR-vaccine)', EPI-NYT week 44 1985; 'Mæslinge-parotitis-rubellavaccine (MFR-vaccine)', EPI-NYT week 45 1985; 'Aktuelle problemer', EPI-NYT week 9 1986; 'Gratis MFR-vaccination fra 1. januar 1987', EPI-NYT week 461986.

${ }^{43}$ National Archives, State Serum Institute Administration, journal files, box 63, folder 09-1844-1983; EPI-NYT week 441986.

44 In 19822668 doses were handed out, in 1983: 9416, and in 1984: 11263.

${ }^{45}$ National Archives, State Serum Institute Administration, journal files, box 63, folder 09-1845-1986, letters dated 15 December 1985. 
and in January 1986 the Minister for the Interior announced that the MMR vaccine would be introduced into the childhood vaccination programme as of 1 January 1987, as would a catch-up rubella vaccination programme for young women.

This illustrates that while tight fiscal policy was an important factor in delaying the introduction of the MMR vaccine, the local initiative resulted in other concerns becoming more important. Epidemiology, and the need to maintain central control over health care systems, seem ultimately to have overridden fiscal concerns. But to introduce MMR, the three diseases had had to be reframed. Rubella and CRS continued to be the main concern for the health authorities, only the strategy changed. Measles had been considered harmless for decades, but as immunisation had gradually become a matter of international attention, this view was replaced by a focus on the possible risks. The earlier view that it was largely chronically ill children who were at risk became blurred. Among the public, mumps was increasingly believed to cause male sterility, but for the authorities it was more a matter of the considerable costs associated with mumps-related hospitalisations. When the MMR programme was finally introduced, the vaccine and its implications had been under scrutiny for a long time. It was known exactly what problems the vaccine would solve, the degree of efficacy, duration and possible side effects, and what the epidemiological and economic consequences would be. Furthermore, there was reason to believe that the uptake would be high because of the local support and the parental interest, as indeed proved to be the case.

\section{MMR Introduction in the Netherlands}

In the Netherlands both rubella and measles were regarded as serious ${ }^{46}$. As early as 1964 the Institute of Public Health (RIV, later RIVM) had begun studying both, with a view to producing vaccines for use in their NIP. By 1971 an HPV77 rubella strain obtained in the USA had been further attenuated, giving a vaccine known as HPV77-RK5. Trials conducted in 1971 and 1972 showed that this appeared to be comparable with commercial vaccines in terms of effectiveness and safety. By 1973 the RIV had concluded that the HPV77-RK5 vaccine should be added to the NIP and, starting in 1974, 11-year-old girls were offered this rubella vaccine. ${ }^{47}$ Development of a measles vaccine rested initially on the hope that an inactivated measles vaccine could be combined with the existing DPTPolio vaccine then being used with great success. Unconvinced by reports of potential risks involved in use of inactivated measles virus, ${ }^{48}$ the RIV succeeded in producing a five component DPTP-M in 1969. In 1970 this was tested in small-scale trials. However, the results were disappointing. ${ }^{49}$ Moreover, not only were some Dutch experts starting to favour live virus vaccine, but political pressures were mounting. Responding both to medical and public opinion, and in view of fact that success was proving elusive, politicians were unwilling to wait for the RIV to produce its vaccine. The result was that measles vaccination began in 1976 using Attenuvax, purchased from Merck. The RIV then set about preparing its own live measles vaccine, using a strain obtained under license from Merck. This was introduced in 1981, by which time measles vaccination had been a striking success. Cases reported had fallen from more than 2000 in 1976 to less than

\footnotetext{
46 On measles, see F.M. Polak 'Mazelenvaccinatie' Nederlands Tijdschrift voor Geneeskunde, 112, 42 (1968), 1905-9.

47 Gezondheidsraad (Health Council of the Netherlands) (1971). Report number 707/69.

48 V.A. Fulginiti and C.H. Kempe, 'Killed-Measles-Virus Vaccine', The Lancet, 290, 7513 (1967), 468.

${ }^{49}$ Ulrike Lindner and Stuart S. Blume, op. cit. (note 10).
} 
a hundred per annum by the early 1980s. By contrast, and as in Denmark, mumps was regarded as a trivial disease of childhood. The institute had made no efforts to develop a mumps vaccine. Merck's Mumpsvax was available in the Netherlands. Merck had applied for permission to import it in 1972, and this had been allowed. However, the Dutch Health Council had decided there was no reason to start mass vaccination.

The introduction of MMR in the Netherlands must be understood in terms of three discussions which led up to it: (a) the alignment of measles and rubella vaccination schedules; (b) the decision to vaccinate against mumps; and then (c) procurement of the vaccine. Analytically they can be distinguished, though in practice the three discussions were interconnected.

In 1979 the Chairman of the Dutch Health Council established a consultative body on immunisation (CBI), which would advise on and support the NIP. It was here, and in a sub-committee, that advice to the Minister of Health was prepared.

While the Netherlands had limited rubella vaccination to 11-year-old girls, as noted earlier the USA had adopted a strategy aimed at stopping circulation of the virus. In the United States all children, boys and girls, were vaccinated against rubella at the age of fifteen months. In March 1982 the CBI began to discuss the suitability of the Netherlands' rubella vaccination strategy. ${ }^{50}$ Sweden, it appeared, had recently switched to universal rubella vaccination, but using a 'combined' strategy. All children were vaccinated at fifteen months and then again at twelve years, though not with the rubella vaccine alone. Sweden had started using the combination MMR vaccine. Should the objective be to stop circulation of the virus? If so, how could this best be achieved? Mathematical (simulation) modelling of an epidemic could provide an answer. In April the committee agreed to recommend that such a modelling exercise be commissioned. ${ }^{51}$ The Health Council then received an official request from the Minister for advice on the appropriate rubella strategy. A sub-committee was established in order to prepare this advice, under the chairmanship of Professor van der Veen. ${ }^{52}$ It began its work in April 1983.

In the course of 1983, the sub-committee gradually became convinced that the rubella vaccination strategy should be changed. A number of arguments played a role. Research elsewhere suggested that the American approach, or a combined one involving a second shot for 11- or 12-year-old girls, would greatly reduce the number of rubella infections. In November 1983 the committee noted that, with a combined rubella strategy, the number of cases of CRS would fall from eighteen to ten per annum: all in families which had refused vaccination. ${ }^{53}$ Increasing numbers of European countries were now following the American (or the combined) strategy. Simulation modelling suggested that, using the combined strategy, virus circulation could be greatly reduced. ${ }^{54}$ Not, however, in the small communities in the Netherlands opposed to vaccination on religious grounds. The model suggested that the risk of CRS would then be higher in these communities than elsewhere. Committee members felt this was no reason to question a strategy deemed to be in the interest of the majority. By January 1984 the sub-committee had agreed that the current rubella strategy should be replaced. If both boys and girls were to be vaccinated at the ages of one and nine years, circulation of the rubella virus could be halted within five

\footnotetext{
${ }^{50}$ National Archives, Gezondheidsraad, inventory number 1511.

51 National Archives, Gezondheidsraad, inventory number 1511.

52 Professor of Medical Microbiology at the Radboud University, Nijmegen.

53 National Archives, Gezondheidsraad, inventory number 387.

${ }^{54}$ National Archives, Gezondheidsraad, inventory number 383.
} 
to ten years. Some discussion of which rubella strain RIVM should use had taken place. Ultimately it was agreed to leave this technical issue to the RIV(M). The sub-committee's report then went to the parent $\mathrm{CBI}$ committee.

The CBI had begun to consider the possibility of mumps vaccination a few years previously. When it did so, in 1980, there had been virtually no prior discussion in the Dutch medical community. Apart from one or two brief references to the development of a triple vaccine in the USA, the principal medical journal, the Nederlands Tijdschrift voor Geneeskunde, had had nothing to say about mumps prior to $1975^{55}$. In that year Professor van der Veen had written, presciently, that while the mumps vaccine was safe and offered protection, there seemed little reason to introduce it on a large scale. He continued:

Perhaps arguments for mumps vaccination will follow from analyses of costs. If in the Netherlands mumps vaccine was administered together with measles in the NIP, the purchase and distribution costs would amount to some 2 million guilders per annum. We have no information regarding the benefits. ${ }^{56}$

Noting that the duration of protection was unclear and acknowledging the risks of infection moving to different age groups, he concluded that the time was not ripe for general mumps vaccination. For some years, no further discussion followed.

When the CBI did begin to discuss mumps vaccination, disagreement emerged among committee members regarding what evidence was most relevant. ${ }^{57}$ One member, a microbiologist, attached particular weight to what was known of the disease. Mumps in children was relatively innocuous, and mumps-related mortality was minimal. Moreover, little was known of the duration of protection that vaccination would provide. There was the risk of circulation being shifted to older age groups. ${ }^{58}$ Another member, a Belgian virologist, pointed to experience abroad. The vaccine was already being used in the USA, Germany and Sweden. A representative of the government Health Inspectorate noted the likelihood that the European Parliament would recommend harmonisation of vaccination schedules in Europe: mumps vaccination was a principal difference between schedules in different European countries. Economic arguments were introduced. It was suggested that the cost of providing the vaccine would be less than costs associated with the hospital admission of mumps patients. Other things being equal, money could be saved. Moreover, many general practitioners were offering mumps vaccination to parents who wanted their children vaccinated against mumps. Distribution of mumps vaccine had risen: from 1500 doses in 1972 to well over 10000 in 1980. Crucially, economic considerations were becoming more significant in the committee's deliberations. Looking at the numbers admitted to hospital with mumps, and the lengths of stay, the Health Inspectorate had estimated that in 1979 these hospital costs had been twice what had been spent on measles vaccine. ${ }^{59}$

When subsequently the Minister formally requested the Health Council to advise on the desirability of mumps vaccination, it was agreed that the recently established rubella sub-committee would consider mumps too. When the sub-committee first met (in April 1983) it appeared that one of the arguments for mumps vaccination had lost some of its force. The number of doses imported annually was now falling. Nor was the seriousness

\footnotetext{
55 Two articles appeared in 1975. Thereafter nothing more on mumps was published until 1984.

56 J. van der Veen, 'Algemene inenting van kinderen tegen bof?', NTvG, 123 (1975), 714-15. Our translation.

57 National Archives, Gezondheidsraad, inventory 1509.

58 This concern had not applied to the rubella and measles vaccines produced at RIV, but, in contrast, the duration of those two vaccines were a major concern in the Danish SSI, where the vaccines were imported, not produced.

${ }^{59}$ National Archives, Gezondheidsraad, inventory 1510.
} 
of the condition a major concern, since prevailing medical opinion was still that serious complications were rare. Admittedly some countries were vaccinating on the grounds that boys should be protected against the risks of contracting orchitis at an older age, although the link with sterility had not been proven. The duration of protection provided by the vaccine, and the consequent risk of enhanced virus circulation among older age groups, remained a source of uncertainty. Available data were inadequate for mathematical modelling to be of much value. Two arguments in favour of mumps vaccination gradually came to dominate the committee's deliberations. One referred to practice elsewhere. Dutch experts were impressed by data from the USA showing an enormous fall in the number of reported cases of mumps. Data from Sweden, where the trivalent MMR vaccine had been introduced, were also noted. At the same time, it was increasingly accepted that Dutch vaccination schedules should be harmonised with those of other European countries. ${ }^{60}$ The second important argument related to costs and benefits. Although data for much more than a back-of-the-envelope calculation were not available, potential savings to the health care budget figured largely in the committee's discussions.

In May 1984 the parent committee (CBI) discussed the report it had received from its rubella-mumps sub-committee. ${ }^{61}$ By this time the Health Council advice to the Minister was becoming clear.

The arguments relating to rubella vaccination (stopping virus circulation) and mumps vaccination (in essence, saving money on the costs of hospitalisation, although precise data were not available) ${ }^{62}$ were quite different. However, both arguments were taken to support the conclusion that boys and girls should be vaccinated twice (at fourteen months and nine years) against both infections. Cases of CRS would be reduced by half, though complete elimination was not anticipated, and there was a likelihood of CRS becoming concentrated in groups refusing vaccination. The second shot would help deal with the risk of immunity declining over time, but it also reflected what by now was becoming the virtual certainty that the Netherlands would switch to a combined MMR vaccine.

The report also considers whether mumps vaccination should be limited to boys, given that boys seemed to be more susceptible than girls and that adult men faced particular risks (such as of orchitis). However, vaccinating only boys is incompatible with use of the combined vaccine, which would have to be given to all children. Arguments for vaccinating girls too had to be found. One was that a 'significant' number of girls were also admitted to hospital (an average of 115 per annum in the period 1977-82). A second was that vaccinating only half the children would insufficiently reduce virus circulation, so that passive protection of the non-immunised would be limited. Although it was not possible to make precise forecasts, reduction in the circulation of the virus, and potentially its elimination, could be expected. Unlike with the rubella virus, no increase in nonvaccinating communities was anticipated.

In June 1984 the Health Council advised that MMR be introduced to the Dutch immunisation programme. In short, albeit on different grounds, the advice was to give two injections against rubella and mumps. Vaccinating twice against measles was also a

\footnotetext{
${ }^{60}$ In September 1983 a draft resolution had been presented to the European Parliament. Among its articles was this: 'Given the low cost of the (mumps) vaccine and the fact that the cost would be further reduced were the vaccines against measles mumps and rubella to be combined, requests the Commission to encourage Member States to establish programmes for prophylaxis by means of MMR immunization'.

${ }^{61}$ National Archives, Gezondheidsraad, inventory number 1504.

62 In the report, saving children days of missed schooling is also introduced as an argument for mumps vaccination - though not for measles vaccination!
} 
good idea since this was in fact more infectious. Having agreed that, introducing MMR was the easiest and cheapest way of doing it. Financial considerations weighed heavily, both with the Health Council and with the Ministry of Health.

At an early stage, while these discussions were ongoing, the Ministry of Health had requested RIV to consider what the options would be, were the Health Council to advise in favour of mumps vaccination. Acknowledging that this was likely, and that it had no expertise in the mumps field, in 1981 the RIV had begun considering the options. The initial intention was to produce a mumps vaccine that could then be mixed with their existing measles and rubella vaccines. A mumps strain would first have to be obtained from a commercial manufacturer. Anticipating the forthcoming change in the immunisation programme, RIV (that in 1984 acquired responsibilities for environmental health and was reorganised as RIVM), began negotiations with three manufacturers regarding production of MMR under licence.

Considering the different mumps strains being used in commercial vaccines, the preference was for Merck's Jeryl Lynn strain, though political considerations were also in play. ${ }^{63}$ In 1982 the Institute approached Merck's European subsidiary (MSD) to discuss the production of their mumps vaccine under licence. Negotiations soon broke down, however. Merck made clear that it would consider licensing its combined MMR vaccine, but not the single mumps component. When the Minister of Health, following Health Council advice, decided that the country should switch to a combined MMR vaccine, the Institute would have to provide it. How was this to be accomplished? Looking back, the then head of the RIVM's vaccine department recalls:

The end of the story is that we had to forget about our own measles and rubella. We could only do it by producing the threefold vaccine under license from one of the companies. That's what happened. I negotiated with the Belgians, and the French, and with Merck and we ultimately chose for Merck. It was impossible otherwise. . . To start with I tried to get just the mumps, in order to mix it with the measles and the rubella that we already had. The problem - and this was soon clear - was that we'd need new clinical trials for a new MMR vaccine ... . You're talking tens of millions of guilders. And even then it couldn't have been done in the Netherlands because there isn't enough mumps. ${ }^{64}$

In September 1985 the government Minister responsible requested the Health Insurance Council (Ziekenfondsraad) to consider the financial implications of introducing MMR. Despite the fact that no cost-benefit data regarding MMR were available for the Netherlands, the Minister pointed out that 'data from other countries, notably the United States, Switzerland and Austria show that MMR is highly cost-effective. It seems reasonable to conclude that the benefits of MMR vaccination more than balance the costs'. ${ }^{65}$ The new arrangements would take effect in January 1987. From then on MMR vaccine would be given to all children at the ages of fourteen months and at nine years. As in Denmark, uptake was immediately very high.

\section{Discussion and Conclusions}

For Danish and Dutch policymakers, the combination vaccine was only gradually becoming the preferred answer to the problems posed by measles, mumps and rubella. Despite the similarities between the two countries, and even though both introduced

63 Interview with Dr A. Plantinga, Bilthoven, 19 February 1999.

${ }^{64}$ Interview with Professor J. Ruitenberg, Amsterdam, 21 December 1998.

65 National Archives, Gezondheidraad, inventory number 1504. Annex. J.P. van der Reijden (1985). Letter to the health insurance council, dated 10 September 1985. 
MMR vaccine in 1987, the considerations and the decisions underlying its introduction differed. As our comparison shows, Dutch and Danish policymakers viewed the MMR vaccine differently because different strategies towards measles and rubella had already been adopted, and because perceptions of the diseases, interpretations of the evidence and political priorities differed from one country to the other. Ultimately, however, these national specificities were overwhelmed by developments taking place internationally. These are the elements that, we believe, explain why both countries delayed adopting the MMR vaccine, and why ultimately both did adopt it.

Introduction of MMR was delayed based on considerations that made sense in each national context, but which differed from one country to the other. Both countries dealt with the three diseases in ways that reflected national perceptions of the risks and dangers of each disease. In the early 1970s Danish health authorities considered that measles was a threat only to certain risk groups, for which free vaccinations were provided. For most children living in mainland Denmark measles was seen as an unpleasant, but essentially harmless episode. The Dutch health authorities considered measles a more general threat and set about developing a measles vaccine for use in the NIP. In the Netherlands universal measles vaccination began in 1976. The two countries differed also in their approach to rubella, though in both countries this was seen as potentially dangerous because of the risk of foetal rubella syndrome. In 1969 the SSI in Denmark developed a method of screening blood samples for rubella virus. Women who were pregnant and infected would have a right to an abortion. In contrast, the RIV in the Netherlands produced a rubella vaccine that was introduced in 1974 to 11-year-old girls to ensure their immunity prior to pregnancy. In the early 1970s, in other words, both countries viewed rubella as a problem of individual women, though they construed the problem differently and adopted different strategies for avoiding the birth of CRS-infected babies. In neither country was mumps regarded as a problem.

Commitment to the existing strategies, which seemed to be working satisfactorily, was a second factor in both countries' 'delayed' introduction of MMR vaccine. We can see this commitment as a form of technological path dependency, though the technologies differed between the countries. The blood screenings continued to be the preferred way to control rubella in Denmark, despite the National Board of Health suggesting that rubella vaccination be introduced. There was an unwillingness to abandon a technology that had been successfully introduced and deployed. The Dutch RIV(M) had developed and produced a rubella vaccine, which was also being used successfully. Here too there was a reluctance to abandon technology that had been developed in-house and was being used successfully.

The question then is that of how MMR was eventually put on the agenda, given that the third component, mumps, was regarded as unimportant. The process in both countries reflects changes at the national level as well as the growing influence of developments at the international level.

Controlling the spread of infectious diseases through expanding immunisation programmes was receiving growing attention at the international level. Furthermore, the role of prevention and primary health care received growing political attention during the 1970s. In 1974, the World Health Assembly had established the Expanded Programme of Immunization, according to which surveillance of and immunisation against 
a number of serious diseases, including measles, was to be extended. ${ }^{66}$ As mentioned, the Thirtieth World Health Assembly adopted the 'Health for all by the year 2000' programme in 1977 . The ambition was that 'by the year 2000, all people in all countries should have a level of health that will permit them to lead a socially and economically productive life' ${ }^{67}$ The following year, the Declaration of Alma-Ata was adopted by the International Conference on Primary Health Care, convened jointly by WHO and UNICEF. The declaration emphasised the importance of primary health care in order to "protect and promote the health of all the people of the world. ${ }^{\text {'6 }}$ In 1979 the 'Global Strategy for health for all by the year 2000' was launched when the Thirty-second World Health Assembly adopted the WHA32.30 resolution and endorsed the Alma-Ata declaration. ${ }^{69}$ HFA2000 was ratified by the WHO European Region in 1984. This was to be followed by increased political commitment to, among other things, immunisations. ${ }^{70}$ Also in 1984, several influential organisations, including the WHO, UNICEF, the World Bank and the Rockefeller Foundation, met in Bellagio, Italy, for a conference on child health. ${ }^{71}$ The ambition was to sharpen focus on immunisation against childhood diseases, again including measles.

The Danish authorities paid considerable attention to the HFA2000 programme, and its implications and implementation were discussed and analysed widely. HFA2000 was used as an argument for MMR introduction, both in the medical journals and in the Parliament. The 1986 proposal for a parliamentary resolution to introduce the combination vaccine, noted earlier, also stated that 'the MMR vaccination is a natural means to advance the World Health Organization goal of health for all by the year 2000'. ${ }^{2}$ While these references to international discussion did not become a determining factor, they did put the obligation to immunise against measles on the agenda.

International debates and practices also influenced the Dutch discussion, but differently. While WHO obligations seem not to have had the same weight, the potential harmonisation of European vaccination schedules played an important role in putting mumps vaccination on the agenda. Over the course of the 1980s, Denmark looked principally to the rest of Scandinavia, though not necessarily with the ambition to harmonise vaccination schedules across the region.

Though it worked differently, in the 1980s both Denmark and the Netherlands were increasingly interested in and influenced by the strategies of other countries. In both countries also, the policymaking process was being transformed by reliance on new tools of policy analysis. These included, in the Netherlands, mathematical modelling of disease epidemiology that enabled the effects of different vaccination strategies on CRS incidence to be compared. In Denmark cost-benefit analyses quantified the societal savings that could be achieved by introduction of the MMR vaccine. But before any decision to introduce MMR could be taken, or justified politically, mumps would have had to be

66 Sidsel Roalkvam, Desmond McNeill and Stuart S. Blume, op. cit. (note 1), $7 \mathrm{ff}$.

${ }^{67}$ World Health Organization, op. cit. (note(36), 31.

${ }^{68}$ Declaration of Alma Ata: International Conference on Primary Health Care, Alma Ata, USSR, 6-12 September 1978 (Geneva: World Health Organization, 1978).

${ }^{69}$ World Health Organization, op. cit. (note 36), 7.

70 Ibid., 53.

${ }^{71}$ William H. Foege, The Task Force for Child Survival: Secrets of Successful Coalitions (Baltimore: Johns Hopkins University Press, 2018).

72 'Forslag til folketingsbeslutning om indførelse af MFR-vaccination', Tillaeg A til Folketingstidende, Folketingsåret 1985-86 (Copenhagen: J.H. Schultz, 1987), 4292. 
reframed as a disease in need of control. ${ }^{73}$ In both countries the focus came to be on the financial argument: mumps caused significant numbers of hospitalisations annually which was expensive - and could be prevented through the combination vaccine at no extra cost.

This reconstruction, or reframing, of mumps points towards an issue particular to the introduction of combination vaccines. Few historical studies have analysed the introduction of combination vaccines, though these do present policymakers with a distinctive challenge compared to monovalent vaccines. ${ }^{74}$ The MMR vaccine protects against three diseases that are quite different in terms of the risks they pose and to whom: rubella to women of childbearing age, mumps to adult men, and measles to children. Introduction of the combination vaccine posed a discursive as well as a technical challenge. To introduce the MMR vaccine, the diseases had to be framed in such a way that combining the antigens and administering them simultaneously, according to an identical schedule, could be justified. This discursive challenge underlies Dutch policymakers debating the relative significance of different forms of evidence for mumps vaccination or seeking a justification for vaccinating girls. The MMR vaccine could only be introduced (in either country) when it could be convincingly argued that the public health would benefit if children were vaccinated twice against all three diseases, so that, if not the problems, then the solutions had been harmonised.

In contrast to today's emphasis on 'evidence-based' decision-making, epidemiology was only one factor in the complex series of decisions and trade-offs that eventually led to the introduction of MMR in Denmark and the Netherlands. Despite the quite similar public health contexts, the seriousness of the three diseases were differently interpreted in the two countries and interpretations were neither fixed nor agreed on either. The different trajectories in the two countries reflected differences in political priorities, structures and hierarchies of power. In Denmark the counties played a role that had no equivalent in the Netherlands. Path dependencies also had a major influence on the policy process. Introduction of MMR came at a price, and that price differed between these two countries. For the Netherlands it entailed abandoning domestic rubella and measles vaccines. For Denmark it entailed abandoning a different technology, developed to identify at-risk individuals. For both countries it entailed reframing mumps as a significant public health problem - once calculations had suggested money could be saved.

Finally, and despite differences in detail, in both countries changes in the international context - at a time in which international health was giving way to global health ${ }^{75}$ - had a crucial influence on the development of vaccination policy. Politically, it was becoming more and more important to align national policy with an evolving international agenda (in Denmark notably that of the WHO) or with the practices of neighbouring countries (as in the Netherlands). Global pressures were becoming hard to resist even

\footnotetext{
73 Elena Conis, Vaccine Nation: America's Changing Relationship with Immunization (Chicago: Chicago University Press, 2015), 63-84.

${ }^{74}$ Stuart Blume and Janneke Tump, 'Evidence and Policymaking: The Introduction of MMR Vaccine in the Netherlands', Social Science \& Medicine, 71 (2010), 1049-55; K. Maman, Y. Zöllner, D. Greco, G. Duru, S. Sendyona and V. Remy, 'The Value of Childhood Combination Vaccines: From Beliefs to Evidence' , Human Vaccines \& Immunotherapeutics, 11, 9 (2015), 2132-41; Aiko Shono and Masahide Kondo, 'Mothers' Preferences Regarding New Combination Vaccines for their Children in Japan, 2014', Human Vaccines \& Immunotherapeutics, 13, 4 (2017), 766-71.

75 Theodore M. Brown, Marcos Cueto and Elizabeth Fee, 'The World Health Organization and the Transition from International to Global Public Health', American Journal of Public Health, 96, 1 (2006), 62-72.
} 
for wealthy industrialised countries. This was a period in which profound changes were taking place in vaccination policymaking processes, as a result of the growing saliency of new policy-analytic tools, of attempts at reducing the scope and scale of state action, and of increasingly powerful forces of globalisation.

This study of the introduction of MMR vaccine in two West European welfare states, each with access to its own national vaccine institute, has shown the manifold changes to which vaccination policy responds. The problems to which vaccination was believed to be the answer were extending well beyond the prevention of high-mortality diseases (a process which continues to this day). Responding to national concerns, practices and priorities, the non-introduction of MMR vaccine at the start of the 1980s, despite its introduction elsewhere, made perfect sense in Denmark and in the Netherlands. In today's vaccination politics, a delay of a decade or more to introduce a vaccine against an infectious disease, no matter local perceptions or priorities, has become difficult to justify. 